\title{
Türkiye'nin Almanya, Rusya Ve Çin İle Ticari İlişkileri: Girdi-Çıktı Analizi İle Bir Uygulama
}

\section{Turkey's Commercial Relationship With Germany, Russia And China: An Application With Input-Output Analysis}

\author{
Ş. Mustafa ERSUNGUR* \\ Turgut BAYRAMOĞLU** \\ Hakan PABUÇCU ${ }^{* * *}$
}

\begin{abstract}
Özet
Almanya, Rusya ve Çin özellikle ticari ilişkiler bakımından Türkiye için özel bir öneme sahiptir. Türkiye’nin ithalatı açısından bu ülkeler ilk üç sırayı almaktadır. Bu sebeple çalışmada adı geçen ülkeler ile Türkiye arasındaki dış ticaret ilişkisi ve kilit endüstriler 1995, 2000, 2005, 2008 ve 2011 yıllarına ait veriler kullanılarak girdi-çıktı analizi yardımıyla belirlenmeye çalışılmıştır. Elde edilen sonuçlar ışığında; Türkiye için ithalata bağımlı üretim modeli koşullarının gerçekleştiği, diğer ülkeler için ise ilk üç sektörde böyle bir durumun gerçekleşmediği görülmüştür. Türkiye'nin ithal girdi ürünleri açısından dışa bağımlı bir ülke konumunda olması önemli bir problem olarak tespit edilmiş ve bu durumun kilit endüstriler açısından yurt içi bağımlaşmayı azalttığı sonucuna ulaşılmıştır.
\end{abstract}

Anahtar Kelimeler: Dıș ticaret, İthalata Bağımlılık, Kilit Endüstriler, Girdi-Çıktı Analizi.

\begin{abstract}
Germany, Russia and China have a key importance in terms of international trade relations for Turkey. Mentioned countries take at first three places in Turkey's imports. For this reason, in order to determine the key sectors and international trade relationship between Turkey and the mentioned countries, input-output analysis by using the data for the years 1995, 2000, 2005, 2008 and 2011 has been made in this study. The obtained results show that the import dependent economy model is valid for Turkey but not valid for the other countries in first three sectors. Turkey is a foreign dependent country in terms of imported input products. As a result of the study this dependency is a major problem and it has reduced the domestic dependency for key sectors.Keywords: Foreign trade, Import dependency, Key Industries Input-Output Analysis.
\end{abstract}

\section{Giriş}

Almanya, Rusya Federasyonu ve Çin Halk Cumhuriyeti, Türkiye'nin diş ticaretinde önemli bir yere sahiptir. Ülkemizin son yıllardaki ithalatında bu ülkeler ilk üç sırayı almaktadır. Dolayısıyla, bu çalışmanın amacı, ilgili ülkelerin Türkiye ile ticari ilişkilerini araştırmak ve girdi-çıktı analiziyle ülkelerin ekonomilerinde kilit endüstrilerini ve ithalata bağımlı olan sektörlerini tespit etmektir.

Çalışmada giriş bölümünden sonra ilgili ülkelerin ekonomik ve ticari yapıları ile belli başlı ekonomik göstergeleri tablolar halinde verilmiștir. Daha sonra bu ülkelerin Türkiye ile olan ticari ilişkileri verilmiş, uygulama bölümünde ise bu amaca yönelik olarak World InputOutput Database (WIOD)'den alınan ülkelere ait 1995-2011 dönemini kapsayan y1llara ait

\footnotetext{
* Yrd. Doç. Dr., Atatürk Üniversitesi İktisadi ve İdari Bilimler Fakültesi, E-mail: ersungur@atauni.edu.tr ** Yrd. Doç. Dr., Bayburt Üniversitesi İktisadi ve İdari Bilimler Fakültesi, E-mail: tbayramoglu@bayburt.edu.tr *** Yrd. Doç. Dr., Bayburt Üniversitesi İktisadi ve İdari Bilimler Fakültesi, E-mail: hpabuccu@bayburt.edu.tr
} 
Girdi-Çıktı tablolarından yararlanılarak gerekli analizler yapılmıştır. Elde edilen sonuçlar doğrultusunda çalışmanın sonuç ve değerlendirme kısmında bulgular verilerek gerekli yorumlar yapılmıştır.

\section{Çin, Almanya ve Rusya'nın Ticari Yapıları}

Çin, Almanya ve Rusya yaptıkları ihracat ve ithalat miktarları ile dünya ekonomisini etkilemektedirler. Bu üç ülkenin ekonomik yapıları farklı olsa da özellikle ekonomik açıdan Türkiye için önemleri bir hayli fazladır. İster hasıla büyüklükleri ile isterse büyüme göstergeleri ile farklılıklar göstermekte olan bu ekonomiler Türkiye'nin en fazla ithalat yaptığ üç büyük ekonomik yapıdır. Türkiye'nin ticaret hacmi 2014 yılı için Çin Halk Cumhuriyeti ile 27,779 milyar dolara, Almanya ile 37,516 milyar dolara ve Rusya Federasyonu ile ise 31,231 milyar dolara ulaşmıştır. Ayrıca ithalat ve ihracat oranlarına ise Tablo 2'den bakılabilir.

Tablo.1: Çin Halk Cumhuriyeti, Almanya ve Rusya Federasyonu: GSYH ve Büyüme Oranları (2005-2015, Milyon ABD Doları)

\begin{tabular}{|c|c|c|c|c|c|c|c|c|c|}
\hline & \multicolumn{3}{|c|}{ Çin Halk Cumhuriyeti } & \multicolumn{3}{|l|}{ Almanya } & \multicolumn{3}{|c|}{ Rusya Federasyonu } \\
\hline Yillar & GSYH & KBG & $\begin{array}{l}G \\
(\%)\end{array}$ & GSYH & KBG & $\begin{array}{l}\mathbf{G} \\
(\%)\end{array}$ & GSYH & KBG & $\begin{array}{l}G \\
(\%)\end{array}$ \\
\hline 2005 & 2291432 & 2.717 & 12,4 & 2861339 & 38,971 & 0,3 & 764016 & 8,927 & 2,06 \\
\hline 2006 & 2751945 & 3,045 & 12,5 & 3002293 & 40,459 & 1,3 & 989932 & 9,687 & 1,9 \\
\hline 2007 & 3542363 & 3,459 & 13,9 & 3439777 & 41,834 & 0,3 & 1299703 & 10,532 & 3,19 \\
\hline 2008 & 4564509 & 3,772 & 7,1 & 3752505 & 42,367 & -2 & 1660848 & 11,089 & $-3,25$ \\
\hline 2009 & 5071146 & 4,100 & 11,7 & 3417799 & 40,088 & 0,9 & 1222646 & 10,219 & 1,08 \\
\hline 2010 & 6005388 & 4,514 & 10,0 & 3417095 & 41,788 & 0,8 & 1524917 & 10,675 & 1,26 \\
\hline 2011 & 7441981 & 4,919 & 8,7 & 3757698 & 43,306 & 1,3 & 1904791 & 11,121 & 1,19 \\
\hline 2012 & 8471426 & 5,275 & 8 & 3539615 & 44,223 & $-0,5$ & 2016110 & 11,493 & 0,05 \\
\hline 2013 & 9518402 & 5,652 & 7,6 & 3745317 & 43,433 & 0,4 & 2079022 & 11,615 & 0,35 \\
\hline 2014 & 10430590 & 6,032 & 7,2 & 3868291 & 44,755 & 0,8 & 1849940 & 11,490 & $-0,74$ \\
\hline 2015 & 11156254 & 6,414 & 6,8 & 3296008 & 45,269 & 0,4 & 1296265 & 11,038 & $-3,83$ \\
\hline
\end{tabular}

Kaynak: Trading Economics, http://www.tradingeconomics.com., E.T. 06.11.2016.

Tablo 1, üç ülkenin gayri safi yurt içi hasıla (GSYH), kişi başına düşen milli gelir (KBG) ve büyüme rakamlarını (G) göstermektedir. Çin Halk Cumhuriyeti için özellikle hasıla rakamları rekor seviyelerde artışlar göstermiştir. En düşük büyüme rakamı 2015 'de \%6,8 olmakla beraber 2007 ler de \% 13 lere kadar çıkmıştır. Bu rakam dünyada en fazla büyüyen ekonomi olduğunu göstermektedir. Çin, 2015 yılı verilerine göre 11 milyar dolarlık hasıla ile ikinci en büyük ekonomi seviyesine ulaşmıştır. Almanya gelişmiş bir ülke olarak 3 milyar dolarlık hasıla ile Japonya'dan sonra dördüncü büyük ekonomidir. Almanya'nın büyüme rakamları iyi değildir. Bunu sebebi olarak gelişmiş ülke olması ve 2008 Küresel Ekonomik Krizi gösterilebilir. Almanya 2008 yılında \% 2 küçülme göstermiştir. Ancak 2015 yılı için 45,269 bin dolarlık kişi başına düşen geliri ile Almanya çok iyi seviyededir. Rusya Federasyonu ise 2013 yılına kadar yurt içi hasılasını sürekli artırmış ancak 2013 yılından sonra AB'nin Ukrayna Krizi sebebi ile ekonomik yaptırımları ve petrol fiyatlarındaki hızlı düşüş sebebi ile gerilemiştir. Rusya'nın 2013 yılından sonra büyüme rakamlarının negatife düştüğü söylenebilir. Rusya'nın kişi başına gelir rakamları ise Dünya Bankası sınıflandırmasına göre üst orta gelir grubunda bulunmaktadir.

Tablo.2: Türkiye’nin Rusya Federasyonu, Çin Halk Cumhuriyeti ve Almanya ile Dış Ticaret Bileşimi (2016, Milyon Dolar)

\begin{tabular}{|l|r|r|r|r|r|r|r|r|r|}
\hline \multirow{2}{*}{ Yıllar } & \multicolumn{4}{|c|}{ Çin } & \multicolumn{3}{c|}{ Almanya } & \multicolumn{3}{c|}{ Rusya Federasyonu } \\
\cline { 2 - 11 } & İhracat & İthalat & \multicolumn{1}{|c|}{ Denge } & İhracat & İthalat & Denge & İhracat & İthalat & \multicolumn{1}{c|}{ Denge } \\
\hline 2005 & 549 & 6,885 & $-6,335$ & 9.455 & 13.633 & -4.178 & 2.377 & 12.905 & -10.528 \\
\hline 2006 & 693 & 9,669 & $-8,976$ & 9.686 & 14.768 & -5.081 & 3.237 & 17.807 & -14.568 \\
\hline 2007 & 1.039 & 13,234 & - & 11.993 & 17.539 & -5.546 & 4.726 & 23508 & -18.781 \\
& & & 12,194 & & & & & & \\
\hline
\end{tabular}




\begin{tabular}{|c|c|c|c|c|c|c|c|c|c|}
\hline 2008 & 1.434 & 15,658 & $\begin{array}{r}- \\
14,220\end{array}$ & 12.951 & 18.687 & -5.735 & 6.481 & 31.364 & -24.882 \\
\hline 2009 & 1.599 & 12,662 & $\begin{array}{r}- \\
11,063\end{array}$ & 9.783 & 14.096 & -4.313 & 3.202 & 19.718 & -16.516 \\
\hline 2010 & 2.259 & 17,180 & 14,921 & 11.479 & 17.549 & -6.070 & 4.631 & 21599 & -16.968 \\
\hline 2011 & 2.466 & 21,692 & $\begin{array}{r}- \\
19,226\end{array}$ & 13.950 & 22.985 & -9.034 & 5.992 & 23.952 & -17.960 \\
\hline 2012 & 2.833 & 21,295 & $\begin{array}{r}- \\
18,461\end{array}$ & 13.123 & 21.400 & -8.276 & 6.682 & 26.625 & -19.942 \\
\hline 2013 & 3.600 & 24,685 & $\begin{array}{r}- \\
21,085\end{array}$ & 13.696 & 24.182 & $\begin{array}{r}- \\
10.485\end{array}$ & 6.964 & 25.064 & -18.100 \\
\hline 2014 & 2.861 & 24,918 & $\begin{array}{r}- \\
22,057\end{array}$ & 15.147 & 22.369 & -7.222 & 5.943 & 25.288 & -19.345 \\
\hline
\end{tabular}

Kaynak: ITC, Trade Map, http://www.trademap.org/Bilateral_TS.aspx

Tablo 2'deki değerlere bakıldığında Çin ile Türkiye arsındaki ticaretin zaman içerisinde sürekli arttığı gözlenmiştir. Ancak Türkiye'den Çin'e olan ihracatla ithalat arasındaki fark 2014 yılı verilerine göre 22,057 milyar dolar olarak gerçekleşmiştir. Çin ile Türkiye arasında ticari ilişkiler bakıldığında özellikle ihracatta Türkiye açısından ihracat değerlerinin düşük olduğu tespit edilmiştir.

Dünyada önemli bir pazar haline gelen Çin pazarından Türkiye'nin daha fazla faydalanması için iki ülke arasındaki ticari ilişkilerin daha yakından değerlendirilmesi gerekir. $\mathrm{Bu}$ açıdan bakıldığında ticari potansiyelin düşük olmasında şu hususlar ön plana çıkmaktadır. Türkiye'nin Çin pazarındaki tüketim eğilimlerini ve pazar farklılığını fark etmesi, Çin bölgesindeki bölge içi ticari ilişkilerin çok yoğun olması, Çin'in dünyadaki önemli ticari potansiyele sahip partnerlerinin olması, Çin ile Türkiye arasında özel ticari anlaşmaların olmaması ve Çin pazarında Türkiye'nin yeterince tanınmaması gibi faktörler sayılabilir. Sayılan bu faktörlerin çözüme ulaşması durumunda 2013 yılı için gerçekleşen ihracat rakamı 3,60 milyar seviyesinde iken potansiyelin 8.47 milyar dolar olduğu anlaşılmaktadır (Çelik, 2016;109, 136). İthalat tarafı ile Tablo 2'ye baktığımızda ise 2014 yılında Türkiye ile Çin arasındaki ithalatın gerçekleşen değeri olarak 24,918 milyar dolar olduğu anlaşılmaktadır.

Türkiye ile Almanya arasındaki ticaretin yapısı yine Tablo 2'den anlaşılabilmektedir. 2009 ve 2010 hariç olmak üzere ihracatta sürekli bir artış olduğu yine aynı tarihlerde ithalatta bir azalma olduğu gözlenmektedir. Bunun sebebinin 2008 Küresel Krizi olduğu tahmin edilebilir. Yine Almanya ile yapılan ticarette bütün yıllar boyunca ithalat değerlerinin fazlalığı dikkati çekmektedir. Tablo değerlerine göre Almanya ile Türkiye arasındaki ticaret Almanya'nın lehine görünmektedir.

Rusya ile Türkiye arasındaki ihracat ve ithalat değerlerine Tablo 2'den baktığımızda yine ihracatın ithalata göre çok düşük seviyelerde gerçekleştiği görülmektedir. 2014 yılı verilerine göre Türkiye'den Rusya'ya yapılan ihracat miktarı 5.943 milyar dolar iken ithalat miktarının 25.288 milyar dolar olduğu anlaşılmaktadır. Bu rakamların gerçekleşmesinde Türkiye'nin enerji hammaddesi alımlarının büyük payı vardır.

\section{Çin Halk Cumhuriyeti’nin Ekonomik Yapısı ve Türkiye ile Ticari İlişkileri}

Çin son yıllarda ekonomik olarak kendisinden en fazla bahsettiren ülke olması dolayısıyla her türlü ilgiyi hak etmektedir. Bunda uzun süreden beri yüksek büyüme rakamları, ihracata dayalı büyüme stratejisi, dünyanın üretim üssü olması, düşük enflasyon, fiyat istikrarı ve dış borçlarda azalmaya gitmesinin payı büyüktür (TASAM, 2016). Dünyanın en fazla nüfusuna ve bununla paralel bir şekilde iş gücüne sahip olması, coğrafi alan olarak dünyanın üçüncü ülkesi olması, gelişen ve çok hızlı büyüyen bir ekonomik yapıya sahip olması bu ülkeyi diğerlerinden farklılaştırmaktadır. Çin 2001 yılında Dünya Ticaret Örgütü’ne üye olması ile 
1970'lerde bașlayan reformlarını ve dıșa açılmasını sürdürmüștür. Ortalama olarak 1970'lerde \% 5.9 ve 1980'lerden sonra ise \% 10 büyüme başarısını göstermiştir. 2010 yılına gelince dünyanın en büyük ikinci ekonomisi olmuş ve büyüme rakamlarında düşme görülse de bu trendini halen devam ettirmektedir (McMillan ve Naught, 1992, s. 131; Ersungur ve Ekinci, 2015, s. 734).

Diğer taraftan Çin Uzak Doğu'da Türkiye'nin en büyük ticari ortağıdır. Çin ile yapılan ikili anlaşmalarla Türkiye ticari ilişkilerini sürekli geliştirmiştir. 2000 yılında başlayan ticari ilişkiler sürekli gelişme göstermiştir. 2015 yılı verilerine göre iki ülke arasındaki ticaret hacmi 27 milyar dolara çıkmıştır. Bu rakamın 2.4 milyarı ihracatımızı, 24.8 milyar doları ise ithalatımızı göstermektedir. Ancak Çin ile Türkiye'nin ticari ilişkileri istenen düzeyde değildir (Ekonomi Bakanlığı, 2016). Çin'e olan ihracatımızın istenilen seviyede artırılamamasının arkasında 'Türk Markası' imajının oluşturulamamış olması, ihraç ürünlerinin çeşitliliğinin artırılamamış olması ve katma değeri yüksek ürünlerin olmamasının etkisi görülmektedir (Konca ve Uysal, 2013, s. 3).

Çin ekonomisinin her geçen gün daha da gelişmesi, daha şeffaf hale gelmesi ülkeye yabancı yatırımcıyı çekecek ve Çin'in partnerlerine daha fazla yarar sağlayacaktır (Sayar, 2007, s. 55). Çin'e başlıca ihraç ürünlerimiz mermer ve doğal taş, krom, bakır, kurşun, çinko cevherleri, kimyasallardan oluşmakta, oto yedek parçaları, gaz türbini, dokuma makinesi gibi çeşitli makineler, deri, yün, pamuk ve halı gibi bazı ürün gruplarının ihracatında da gelişmeler gözlemlenmektedir. Başlıca ithal ürünlerimiz telsiz telefon cihazları, otomatik bilgi işlem makineleri, televizyon kamerası, ses-görüntü cihazları olmaktadır.

Çin sermaye çekme konusunda da başarılı bir ülkedir. Birçok gelişmiş ülke yabancı sermaye çekme konusunda gerilerken Çin özellikle doğrudan yabancı sermaye çekme konusunda başarılı olmuştur. 2014 yılında dünyada en fazla yabancı sermaye çeken ülke konumuna gelmiştir. Çin ekonomisi ile ilgili bir diğer gelişme son y1llarda büyümenin niceliksel unsurlardan niteliğe ağırlık veren bir yapıya bürünmesidir. $\mathrm{Bu}$ açıdan yüksek teknolojili gıda, tarım, emlak ve hizmet sektörleri ön plana çıkmaktadır (Ekonomi Bakanlığı, 2016). Çin ekonomisi ile ilgili yapılan tahminler 2025 'lere doğru milli gelirini 5 kat artıracağı, buna bağlı olarak ihracat ve ithalat rakamlarının artacağı beklenmektedir. Türkiye'nin bu artıştan payına düşeni alması beklenebilir. Çin 12. Beş yıllık planı uygulamaya sokmuş ve ihracata önem vermekle beraber ithalat potansiyeline dayalı iç tüketime dayalı büyüme hedeflemektedir (Köse, Uysal, 2011, s. 6). Bu gelişmelerle beraber Çin ekonomisi son yıllarda bir durgunluğa girmiştir. 2008 de başlayıp halen devam eden küresel krizden çıkışın yavaş seyretmesi Çin ekonomisinin büyüme hedeflerini gerçekleştirmede engel olmaktadır. Çin son ekonomik durgunluğu azaltmak için piyasalara para enjekte etmekte, faiz oranlarını artırmakta ve piyasalar canlansın diye hisse senetleri alımları yapmaktadır (Çukurçayır, 2015).

\section{Almanya'nın Ekonomik Yapısı ve Türkiye ile Ticari İlişkileri}

Almanya ekonomisi hasıla büyüklügü, ihracatta gösterdiği yüksek başarı ve AB'nin en yüksek nüfusuna sahip olması ile ön plana çıkan diğer bir ülkedir. Türkiye ile olan tarihsel bağları ve Almanya'da yaşayan üç milyondan daha fazla Türk nüfusu ile ekonomik olarak en büyük partnerimiz durumundadır. Almaya ekonomisi sanayi makinaları, otomotiv ve kimya sektörlerinde ön plana çıkmakta, son zamanlarda ise iletişim teknolojisinde ve hizmetler sektöründe bir atılım yaptığı görülmektedir. Almanya ekonomisinde Euro'nun tedavüle girmesi ve yaşanan ekonomik kriz ile tüketim harcamalarındaki azalış ihracatı ve büyüme rakamlarını düşürmüştür. Öyleki 2009 yılına kadar dünyada en fazla ihracat yapan ülke olan Almanya bu liderliğini Çin'e bırakmak zorunda kalmıştır. Almanya ekonomisi diğer gelişmiş ülkelerden daha fazla büyüme gösterse de 2013 yllına kadar büyümede bir yavaşlama olmuş ancak 2014 'ten sonra ise yine büyüme konusunda bir toparlanma yaşamıştır (Ekonomi Bakanlığ1 
2016). Kişi başına milli geliri 45.900 dolar olan ülkenin yüksek alım gücü ile diğer ekonomileri sürüklediği söylenebilir. Almanya ekonomisi yabancı sermaye çekme konusunda çok başarılı değildir. 2015 verilerine göre doğrudan yabancı sermaye miktarı 31.719 milyon dolardır (World Invest Report, 2016, s. 196).

Türkiye'nin Almanya ile olan ekonomik ilişkilerine bakıldığında ise AB ülkeleri arasında yüksek olduğu görülebilir. Almanya ülkemizin ihracatında birinci sırada, ithalatında ise Rusya ve Çin'in ardında üçüncü sırada gelmektedir. 2014 yılında Almanya'ya olan ihracatımız 15 milyar dolara ulaşmış, ithalatımız ise 22 milyar dolar olarak gerçekleşmiştir (Almanya Ülke Raporu, 2016, s. 3).

\section{Rusya Federasyonu'nun Ekonomik Yapısı ve Türkiye ile Ticari İlişkileri}

Alan açısından dünyanın en büyük ülkesi olan Rusya nüfus problemlerine rağmen nüfus büyüklüğü açısından ve ekonomik olarak önemli bir ülkedir. Rusya ekonomisi özellikle zengin doğal kaynakları ile ön plana çıkmaktadır. Petrol, doğal gaz ve kömür gibi enerji hammadde kaynakları bunların başında gelmektedir. Rusya'nın doğal kaynakları büyük bir varlık olmakla beraber uzun vadede ülke ekonomisinin diğer sektörlerini olumsuz etkilemiş durumdadır. Merkezi planlamaya sahip olan ülke yakıt, enerji ve metalürji gibi ağır sanayi alanında gelişmiş, tüketim ve ileri teknoloji alanlarında aynı başarıyı gösterememiştir.

Sovyetler Birliği'nin dağılması ile ciddi ekonomik problemler yaşayan Rusya serbest piyasa ekonomisine uyumda zorluklarla karşılaşmıştır. Ukrayna Krizi gibi Rusya'nın yaşadığ 1 siyasi krizler sebebi ile uygulanan uluslararası ambargolar ve petrol fiyatlarının düşmesi Rus ekonomini zora sokmuştur. Dış yatırım alma konusunda da Rusya büyük bir düşüş yaşamıştır. Doğrudan sermaye yatırımlarında 2013 yılından bu tarafa 40 milyar dolarlardan 3 milyar dolarlara gerilemişstir (Ekonomi Bakanlığı, 2016).

Rusya ekonomide önemli zorluklar yaşasa da özellikle Türkiye gibi enerji bağımlısı ülkeler için önemli bir ticari partnerdir. Rusya geçiş ekonomisine sahipken Türkiye yeni pazarlar bulma arayışındadır ve ekonomik yapıları gereği birbirlerini tamamlayan yapılara sahiptirler. Rusya ile Türkiye arasındaki ticari ilişkiler SSCB'nin kuruluşuna kadar götürülse de asıl ticari canlanma 1991 yılında imzalanan Ticari ve Ekonomik İşbirliğine Dair Anlaşma ile hızlanmıştır. 1997 yılına kadar ticarette hızlanma bu tarihten sonra ise bir gerileme görülmüştür (TEPAV, 2016, s. 3). 2015 yılında Türkiye ile Rusya arasındaki ticaret hacmi 25 milyar dolar seviyelerine ulaşmıştır. Rusya ile dış ticarette öne çıkan diğer bir gelişme ise dış ticaretin ulusal paralarla yapılmaya başlanmasıdır. Rusya'da birçok Türk Bankası'nın şubeleri bulunmaktadır. Türkiye Rusya da inşaat, gıda, içecek, şişe, cam, beyaz ve kahverengi eşya alanlarda yatırım ve faaliyette bulunurken, Rusya ise Türkiye'de iletişim, yakıt ve enerji, nükleer enerji, demir çelik sanayi gibi alanlarda yatırım ve faaliyetlerde bulunduğu anlaşılmaktadır. İki ülke arasındaki en önemli faaliyet alanlarından birisi de kuşkusuz turizmdir. Son zamanda yaşanan terör olayları ve siyasi karışıklıklar turizm faaliyetlerini oldukça kötü etkilese de (Bayramoğlu, Durmaz ve Ari, 2015, s. 27), Türkiye için Rusya kaynaklı turist sayılarının hatırı sayılır bir ağırlığı vardır. 2015 yılında Türkiye'yi ziyaret eden 40 milyonu aşkın turist sayısının 3.5 milyona yakını Rusya menşelidir (TÜİK, 2016).

\section{Uygulama}

\section{Literatür}

Gerek girdi-çıktı analizi gerekse Türkiye ithalatının konu olduğu birçok çalışma bulunmakla birlikte en yeni ve güncel olanlar ve sonuçlarına değinilmiştir.

Pietroforte ve Gregori (2003)' de ülke ekonomileri için çok önemli bir yeri olan ve hızlı büyüyen bir sektör olan inşaat sektöründe girdi çıktı tablolarından yararlanılarak gelişmekte 
olan altı ülke (Brezilya, Rusya, Hindistan, Endonezya, Çin ve Güney Afrika) için sektörün durumu değerlendirilmeye çalışılmıştır. Çalışmada 1995-2005 yılı verisi kullanılmıştır. Katma değer, brüt çıktı, nihai talep ve ara girdi gibi temel indikatörler kullanılarak sektör incelenmiştir. Ülkeler arasındaki yapısal değişimlerin değerlendirilmesi ve girdi harcamalarının incelenebilmesi için kosinüs benzerlik fonksiyonu hesaplanmıştır.

Ozkan, Akcaoz, ve Fert (2004) çalışmasının amacı 1975-2000 yılları arasında Türk tarım sektöründe enerji kullanımını girdi-çıktı analizi ile belirlemektir. Enerji kullanımının hesaplanması için insan ve hayvan gücü, makineleşme, elektrik, gübre ve yem gibi 36 tarımsal belirleyici sisteme dâhil edilmiştir. Analiz sonucunda toplam enerji girdi ve çıktılarının arttığ1 ve enerji verimliliğinin ise azaldığı buna bağlı olarak ta nihai üretimin de azaldığ edilmiştir. Sürdürülebilir üretim teknikleri, verimli ve yeşil enerji kullanımını teşvik eden politikalarla üreticinin desteklenmesi gerektiği sonuçlarına vurgu yapılmıştır.

Kızılaslan (2009) Türkiye'de vişne üretimi ve bu üretimde kullanılan girdilerin enerji eşdeğerliğini incelemiştir. Veriler vişne üretiminin yoğun olduğu Tokat bölgesinde yapılan ticari teşebbüsler araştırmasından elde edilmiştir. Vişne üretiminde kullanılan girdilerden gübre girdisi $\% 42$ oranla en yüksek enerji eşdeğerliğine sahip çıkmıştır. Gübreyi ise elektrik ve dizel yakıt sırasıyla $\% 22$ ve \% 21 oranla takip etmiştir. Kimyasallar, insan gücü, makineler ve sulama suyu enerji eşdeğerliği düşük çıkmıştır.

Pahlavan, Omid ve Akram (2012)'de seraların ürün verimliliğini tahmin etmek için enerji girdi çıktı tablolarından yararlanarak bir yapay sinir ağı (YSA) modeli oluşturmuşlardır. İran'da tesadüfi örnekleme ile seçilen 26 sera için 2009-2010 yıllarını kapsayan girdi çıktı tabloları oluşturulmuş ve analizde kullanılmıştır. YSA ile elde edilen çıktılar mevcut olanlar ile karşılaştırılmış ve korelasyonları incelenmiştir. Çalışmaya konu olan fesleğen üretiminde en önemli olan parametrenin kimyasal gübre olduğu belirlenmiştir.

Andrew ve Peters (2013)'de çevresel sorunların kaynaklarının belirlenmesi için çok bölgeli girdi-çıktı analizinin bazı engellere rağmen çok iyi bir teknik olduğu vurgulanmıştır. Çalışmada Küresel Ticaret Analiz Projesi (Global Trade Analysis Project) veri tabanı kullanılarak çok bölgeli girdi-çıktı tabloları oluşturulmuştur. Oluşturulan tablolar aracılığı ile karbon ayak izi tahminleri yapılmış ve ilgili birçok konu hakkında belirleyici olan faktörler tartışılmıştır.

Rohman (2013) ICT sektörlerinin Avrupa ekonomilerinde büyüme üzerindeki katkısını girdi-çıktı analizi kullanarak test etmiştir. Sonuçta bu sektörlerin ekonominin geri kalanı üzerindeki çarpan etkisinin 1995-2000 dönemine kıyasla 2000-2005 döneminde önemli ölçüde zayıfladığı ortaya çıkmıştır.

Külekçi ve Aksoy (2014) çalışmalarında Türkiye'deki fistık üretiminde kullanılan girdi ve çıktıların enerji tüketimi üzerindeki etkisini belirlemeye çalışmışlardır. Gaziantep'te ki 147 fistık üretim çiftliğinde yüz-yüze görüşme tekniği ile anketler yaparak veri seti oluşturmuşlardır. Girdi çıktı tabloları oluşturarak, enerji tüketimi, girdi-çıktı oranı, enerji verimliliği, kar-maliyet oranı, net gelir gibi değişkenler üzerinden tartışmalar gerçekleştirmişlerdir. Sonuç olarak, daha verimli ve ekonomik enerji kullanımı için çiftliklerde enerji yönetiminin geliştirilmesi gerektiği belirtilmiştir.

Özdil ve Turdalieva (2014) Türkiye-Kazakistan ekonomilerinin üretim yapılarının karşılaştırmalı olarak incelenebilmesi için girdi-çıktı analizi uygulamışladır. Ülkelere ait girdiçıktı tabloları kullanılarak ileri-geri bağlantı etkileri araştırılmış ülkeler için kilit sektörler belirlenmeye çalışılmıştır.

Ersungur ve Ekinci (2015) Türkiye ve Doğu Asya (Çin, Güney Kore, Japonya ve Tayvan) ülkeleri arasındaki dış ticaret ilişkilerini girdi-çıktı analizi yardımıyla belirlemeye 
çalışmışlardır. Girdi-çıktı akım tabloları kullanılarak 1995-2000-2005-2008-2011 yılları için bahsi geçen ülkelerin ekonomik yapıları ve kilit rol oynayan sektörlerinin belirlenmesi amaçlanmıştır. Sonuçta ithal girdi açısından dışa bağımlılık Türkiye için çok önemli problem olarak ortaya çıkmıştır.

Zhang, Peng ve Sun (2015)'te gelişmiş ülkelerde hizmet sektörünün önemi ve çevresel etkilerinin önemli bir konu olduğu vurgulamış, çok-bölgeli girdi-çıktı modeli kullanılarak 41 ülke ve bölgede hizmet sektörünün tüketim temelli emisyonlarının tahmini yapılmıştır. Sonuçta birçok gelişmiş ülkede hizmet sektöründeki tüketim temelli emisyonların, direkt emisyondan daha fazla olduğu ortaya çıkmıştır. ABD ve Çin için karbon emisyonları üzerinde kilit rol oynayan faktörün servis kategorileri ve üretim sektörü olduğu belirlenmiştir. Ayrıca elde edilen sonuçların iklim üzerindeki, sürdürülebilirlik ve hizmet sektöründe karbonsuzlaştırma üzerindeki etkileri tartışılmıştır.

Gündoğdu ve Saracoğlu (2016) Dünya Girdi-Çıktı veri tabanından (World Input Output Database) elde edilen verilerle Türkiye'nin Küresel değer zincirine katılım trendini incelemiştir. Sonuçta teknoloji yoğun endüstrilerde yüksek teknolojili ürünlerin ithalatının Türkiye'nin küresel pazardaki konumunu daha ileriye taşıyacağı vurgulanmıştır.

\section{Araştırmanın Yöntemi}

Bu çalışmada Türkiye'nin en fazla ithalat yaptığı ülkeler olan Almanya, Rusya ve Çin ile olan ekonomik ilişkilerin yapısı ve kilit rol oynayan endüstrilerin belirlenmesi amaçlanmıştır. $\mathrm{Bu}$ amaca yönelik olarak World Input-Output Database (WIOD)'deki çalışmamızda yer alan ülkelere ait 1995-2011 dönemini kapsayan yılların Girdi-Çıktı tablolarından yararlanılarak ilgili ülkelerin ekonomik yapıları Girdi-Çıktı analizi ile incelenmiştir.

Girdi-Çıktı tabloları ve tablolar üzerinde bazı hesaplamalar yoluyla birçok bilgi ve yorum elde etmek mümkündür. Girdi-Çıktı analizinin avantajı ekonomideki makro ve mikro ölçekli etkilerin değerlendirilmesinde doğrudan ve dolaylı etkileri yakalayabilme yeteneği olarak değerlendirilmektedir (Rohman, 2013; Ersungur, 2016). Örneğin ülkelerin girdi-çıktı tablolarından hesaplanan istatistiklerle, ekonominin ithalata olan bağımlılığının ölçülmesinde kullanılan ters ithalat matrisleri elde edilmektedir. Toplam girdi katsayı matrisi ise yerli girdi katsayı matrisi ve ithal girdi katsayı matrisinin toplamı (eşitlik 1) olarak ifade edilmektedir.

$$
A_{t}=A_{m}+A_{d}
$$

Herhangi bir zaman dilimine ait ters ithalat matrisi eşitlik (2) ile hesaplanmaktadır (Rohman, 2013):

$$
R=A_{m}\left(I-A_{d}\right)^{-1}
$$

Ters ithalat matrislerinin satır toplamları (eşitlik 3) ve sütun toplamları (eşitlik 4) özel anlamalar taşımaktadır. Ters ithalat matrisi satır toplamı ithalatın ileriye doğru bağlantı etkilerini, sütun toplamları ise herhangi bir $j$ endüstrisinin üretimindeki bir birimlik artış1 gerçekleştirebilmek için sistemin içindeki tüm endüstrilerden temin edeceği ithal girdi miktarını gösterir.

$$
\begin{aligned}
& R_{i}=\sum_{i=1}^{n} r_{i j}(i=1,2, \ldots, n) \\
& R_{j}=\sum_{j=1}^{n} r_{i j}(j=1,2, \ldots, n)
\end{aligned}
$$

Ayrıca nihai talep düzeyinde bir artış olduğunda, hangi endüstri malından ne kadar ithal edilmesi gerektiğimi ise $R_{i}$ göstermektedir (Ersungur \& Ekinci, 2015). 


\section{Araştırmanın Bulguları}

Türkiye'nin ithalatında ilk üç sırada bulunan Almanya, Rusya ve Çin'in 1995, 2000, 2005, 2008 ve 2011 yıllarına ait Girdi-Çıktı tablolarından elde edilen veriler, yukarıdaki denklemlere uygulanmış ve Girdi-Çıktı analizi ile ülkelerin kilit endüstrilerini ve ithalata bağımlı sektörlerini belirlemek için Ters Leontief matrisleri ve Ters ithalat matrisleri hesaplanmıştır. Ülkelerdeki sektörlerin dönemler itibariyle yapısal bağınlaşma açısından geriye ve ileriye bağlantı etkilerini gösteren ilk 5 sektöre ait ters Leontief matrislerinin sütun ve satır toplamları aşağıdaki tablolarda verilmiştir.

Tablo 3 'te yıllara göre Türkiye, Almanya, Rusya ve Çin'in ters Leontief Matrisleri sütun toplamları, başka bir deyişle geriye bağlantı etkileri gösterilmektedir.

Tablo 3: Yıllara göre Türkiye, Almanya, Rusya ve Çin'in Ters Leontief Matrisleri Sütun Toplamları (Geriye Bağlantı Etkileri)

\begin{tabular}{|c|c|c|c|c|c|c|c|c|}
\hline & \multicolumn{2}{|c|}{ TÜRKIYYE } & \multicolumn{2}{|c|}{ ALMANYA } & \multicolumn{2}{|c|}{ RUSYA } & \multicolumn{2}{|c|}{ CíN } \\
\hline & $\begin{array}{r}\text { Sek. } \\
\text { No }\end{array}$ & $\begin{array}{r}\text { Sütun } \\
\text { Top. }\end{array}$ & $\begin{array}{r}\text { Sek. } \\
\text { No }\end{array}$ & $\begin{array}{r}\text { Sütun } \\
\text { Top. }\end{array}$ & $\begin{array}{r}\text { Sek. } \\
\text { No } \\
\end{array}$ & $\begin{array}{r}\text { Sütun } \\
\text { Top. }\end{array}$ & $\begin{array}{r}\text { Sek. } \\
\text { No } \\
\end{array}$ & $\begin{array}{l}\text { Sütun } \\
\text { Top. }\end{array}$ \\
\hline \multirow{5}{*}{ e } & 6 & 2,227 & 8 & 2,417 & 3 & 2,463 & 14 & 3,177 \\
\hline & 5 & 2,17 & 26 & & 15 & & 15 & 3,154 \\
\hline & 4 & 2,12 & 3 & & 10 & 2,3 & 12 & 3,136 \\
\hline & 26 & 2,0 & 24 & & 8 & & 5 & 3,088 \\
\hline & 12 & 2,0 & 15 & & 4 & & 10 & 3,051 \\
\hline & 12 & 2,5 & 15 & & 4 & & 14 & 3,287 \\
\hline & 5 & 2,4 & 8 & & 3 & & 15 & 3,183 \\
\hline & 16 & 2,487 & 3 & 2,3 & 5 & 2,2 & 5 & 3,163 \\
\hline & 6 & 2,427 & 5 & 2,258 & 10 & 2,22 & 12 & 3,143 \\
\hline & 14 & 2,422 & 25 & 2,257 & 15 & 2,2 & 10 & 3,069 \\
\hline & 16 & 2,6 & 8 & 2,6 & 15 & & 14 & 3,682 \\
\hline & 12 & 2,631 & 15 & 2,563 & 10 & 2,497 & 15 & 3,563 \\
\hline & 14 & 2,585 & 25 & 2,417 & 25 & 2,428 & 10 & 3,470 \\
\hline & 4 & 2,582 & 3 & 2,3 & 9 & 2,404 & 13 & 3,386 \\
\hline & 5 & 2,56 & 6 & 2,3 & 13 & 2,391 & 12 & 3,347 \\
\hline \multirow{5}{*}{$\stackrel{\infty}{\stackrel{\sim}{~}}$} & $\overline{4}$ & 2,6 & 8 & 2,7 & 15 & 2,9 & 14 & 3,945 \\
\hline & 16 & 2,643 & 15 & 2,671 & 25 & 2,596 & 15 & 3,820 \\
\hline & 5 & 2,58 & 25 & 2,5 & 10 & 2,499 & 10 & 3,725 \\
\hline & 12 & 2,5 & 3 & 2,4 & 12 & 2,450 & 13 & 3,605 \\
\hline & 14 & & 24 & 2,4 & 13 & 2,4 & 4 & 3,533 \\
\hline & 4 & 2,7 & 15 & 2,6 & 15 & 2,970 & 14 & 3,933 \\
\hline & 16 & 2,6 & 8 & & 10 & 2,606 & 15 & 3,792 \\
\hline & 12 & 2,5 & 25 & & 25 & 2,604 & 10 & 3,705 \\
\hline & 5 & 2,5 & 24 & & 13 & 2,465 & 13 & 3,573 \\
\hline & 14 & & 12 & & 16 & 2,4 & & \\
\hline
\end{tabular}

Kaynak: WIOD, World Input-Output Database 'National Input-Output Tables, Released November 2013'ten faydalanılarak hesaplanmıştır.

Tablo 3'e göre 1995 yılında Türkiye'de geriye bağlantı etkisi en yüksek ilk sektör 6 no'lu Ahşap, Ahşap ve Mantar Ürünleri iken, 2. sırada 5 nolu Deri, Deri ve Ayakkabı, 3. sırada ise 4 no'lu Tekstil ve Tekstil Ürünleri yer almaktadır. Almanya'da geriye bağlantı etkisi en yüksek ilk üç sektör 8 no'lu Rafine Petrol ve Nükleer Yakıt, 26 no'lu Diğer Destekleyici ve Yardımcı Ulaştırma Faaliyetleri; Seyahat Acentaları Faaliyetleri ve 3 no'lu Gıda, İçecek ve Tütün'dür. Aynı yılda Rusya'da geriye bağlantı etkisi en yüksek ilk üç sektör 3 no'lu Gıda, İçecek ve Tütün, 15 no'lu Ulaştırma Ekipmanları ile 10 no'lu Kauçuk ve Plastik'tir. Çin'de ise 1995 yılında geriye bağlantı etkisi en yüksek ilk üç sektör 14 no’lu Elektrik ve Optik Ekipmanlar, 15 no'lu Ulaştırma Ekipmanları ile 12 no'lu Temel Metaller ve Metal üretimi'dir. 
2000 yılında Türkiye'de geriye bağlantı etkisi en yüksek sektörler 12 no'lu Temel Metaller ve Metal üretimi, 5 no'lu Deri, Deri ve Ayakkabı ve 16 no'lu İmalat (B.Y.S.) Geri Dönüşüm'dür. Almanya'da geriye bağlantı etkisi en yüksek ilk üç sektör 15 no'lu Ulaştırma Ekipmanları, 8 no'lu Rafine Petrol ve Nükleer Yakıt ve 3 no'lu Gıda, İçecek ve Tütün'dür. Aynı yılda Rusya'da geriye bağlantı etkisi en yüksek ilk üç sektör 4 no'lu Tekstil ve Tekstil Ürünleri, 3 no'lu Gıda, İçecek ve Tütün ile 5 no'lu Deri, Deri ve Ayakkabı iken, Çin'in ise ilk iki sektörü 1995 yılı ile aynı, üçüncü sektör ise 5 no'lu Deri, Deri ve Ayakkabı'dır.

2005 yılında Türkiye'de geriye bağlantı etkisi en yüksek sektör 16 no'lu İmalat (B.Y.S.) Geri Dönüşüm olurken, daha önceki yıllarda ikinci sırada yer alan 5 no'lu Deri, Deri ve Ayakkabı sektöründe geri bağlantı açısından bir gerileme olmuş ve beşinci sırada kalmıştır. Aynı yıl içerisinde Almanya'da geriye bağlantı etkisi en yüksek ilk üç sektör 8 no'lu Rafine Petrol ve Nükleer Yakıt, 15 no'lu Ulaştırma Ekipmanları ve 25 no'lu Hava Taşımacılığı'dır. Aynı yılda Rusya'da geriye bağlantı etkisi en yüksek ilk üç sektör 15 no'lu Ulaştırma Ekipmanları, 10 no'lu Kauçuk ve Plastik ile 25 no'lu Hava Taşımacılığı iken, Çin'de ilk iki sektörde değişiklik yoktur. Üçüncü sektör ise 10 no'lu Kauçuk ve Plastik'tir.

2008 yılına göre Türkiye'de geriye bağlantı etkisi en yüksek ilk sektör 4 no'lu Tekstil ve Tekstil Ürünleri'dir. 2. sırada 16 no'lu İmalat (B.Y.S.) Geri Dönüşüm, 3. sırada ise 5 no'lu Deri, Deri ve Ayakkabı yer almaktadır. 2005 yılı ile kıyaslandığında Almanya ve Çin'de geriye bağlantı etkisi açısından en yüksek sektör de herhangi bir değişiklik yokken Rusya'da ise önceki dönemdeki 15 no'lu Ulaştırma Ekipmanları ve 25 no'lu Hava Taşımacılığı sektörleri yer değiştirmiştir.

2011 yılında Türkiye'de ise ilk beş sektör aynı kalmakla birlikte sıralamalarında bir değişiklik tespit edilmiştir. Ancak daha önceki yıllarla kıyaslandığında Almanya'da geriye bağlantı etkisi en yüksek sektör 15 no'lu Ulaştırma Ekipmanları olurken, 8 no'lu Rafine Petrol ve Nükleer Yakıt ise ikinci sıraya gerilemiştir. Aynı dönemde Rusya'da ise, ilk üç sırada yer alan sektörlerin yerleri bir önceki döneme göre değişmiş ve 15 no'lu Ulaştırma Ekipmanları, 10 no'lu Kauçuk ve Plastik ile 25 no'lu Hava Taşımacılığı şeklinde sıralanmıştır. Çin'in geriye bağlantı etkisi en yüksek beş sektörü 2005 yılına göre herhangi bir değişiklik göstermemiştir.

Tablo 4'te Türkiye, Almanya, Rusya ve Çin'in ters Leontief matrisleri satır toplamları, başka bir ifadeyle ileriye bağlantı etkileri gösterilmektedir.

Tablo 4'e göre 1995 y1lında Türkiye'de ileriye bağlantı etkisi en yüksek ilk sektör 8 no'lu Rafine Petrol ve Nükleer Yakıtken, 2. sırada 12 no'lu Temel Metaller ve Metal üretimi, 3. sırada ise 28 no'lu Finansal Aracılık yer almaktadır. Almanya'da ileriye bağlantı etkisi en yüksek ilk üç sektör 30 no'lu Makine\&Ekipman ve Diğer İş Faaliyetleri kiralanması, 26 no'lu Diğer Destekleyici ve Yardımcı Ulaştırma ile Seyahat Acentaları Faaliyetleri ve 28 no'lu Finansal Aracılık'tır. Aynı yılda Rusya'da ileriye bağlantı etkisi en yüksek ilk üç sektör 17 no'lu Elektrik, Gaz ve Su Temini, 20 no'lu Motorlu Araçlar ve Motosikletler Dışında Toptan Ticaret ve Komisyon Ticaret ile 2 no'lu Madencilik ve Taşocakçılığı'dır. Çin'de ise 12 no'lu Temel Metaller ve Metal üretimi, 9 no'lu Kimyasallar ve Kimyasal Ürünler ile 1 no'lu Tarım, Avcılık, Ormancılık ve Balıkçılık ileriye bağlantı etkisi açısından ilk üç sektördür.

Tablo 4: Yıllara göre Türkiye, Almanya, Rusya ve Çin'in Ters Leontief Matrisleri Satır Toplamları (İleriye Bağlantı Etkileri)

\begin{tabular}{|c|c|c|c|c|c|c|c|c|}
\hline & \multicolumn{2}{|c|}{ TÜRKIIYE } & \multicolumn{2}{|c|}{ ALMANYA } & \multicolumn{2}{|c|}{ RUSYA } & \multicolumn{2}{|c|}{ ÇíN } \\
\hline & $\begin{array}{r}\text { Sek. } \\
\text { No } \\
\end{array}$ & $\begin{array}{l}\text { Satır } \\
\text { Top. }\end{array}$ & $\begin{array}{r}\text { Sek. } \\
\text { No }\end{array}$ & $\begin{array}{l}\text { Satır } \\
\text { Top. }\end{array}$ & $\begin{array}{r}\text { Sek. } \\
\text { No }\end{array}$ & & $\begin{array}{r}\text { Sek. } \\
\text { No } \\
\end{array}$ & \\
\hline & 8 & & & & 17 & & 12 & \\
\hline & 12 & 2,8 & & & 20 & & ? & \\
\hline & 28 & 2,7 & 28 & 3,280 & 2 & 3,784 & 1 & 4,940 \\
\hline
\end{tabular}




\begin{tabular}{|c|c|c|c|c|c|c|c|c|}
\hline & & 658 & 12 & 2,937 & 12 & 3,358 & 2 & 4,52 \\
\hline & 9 & 2,632 & 20 & 2,821 & 23 & 3,123 & 20 & 4,232 \\
\hline & 12 & 3,772 & 30 & 6,282 & 20 & 4,293 & 12 & 6,02 \\
\hline & 28 & 3,665 & 26 & 3,170 & 12 & 3,729 & 9 & 5,402 \\
\hline$\Xi$ & 8 & 3,303 & 28 & 2,928 & 17 & 3,642 & 14 & 4,845 \\
\hline & 9 & 3,294 & 12 & 2,876 & 9 & 2,886 & 2 & 4,780 \\
\hline & 23 & 3,245 & 20 & 2,856 & 21 & 2,847 & 1 & 4,246 \\
\hline & 12 & 4,207 & 30 & 6,689 & 12 & 4,567 & 9 & 6,641 \\
\hline & 23 & 4,107 & 26 & 3,325 & 8 & 4,188 & 12 & 6,251 \\
\hline$\Xi$ & 9 & 3,718 & 28 & 3,310 & 17 & 4,121 & 2 & 6,140 \\
\hline & 2 & 3,537 & 12 & 3,004 & 20 & 4,067 & 14 & 5,130 \\
\hline & 20 & 3,091 & 29 & 2,670 & 2 & 3,117 & 17 & 4,897 \\
\hline & 23 & 4,384 & 30 & 6,748 & 12 & 4,606 & 9 & 6,863 \\
\hline & 4 & 3,576 & 12 & 3,461 & 8 & 4,345 & 12 & 6,798 \\
\hline ๕ & 17 & 3,317 & 26 & 3,417 & 20 & 4,339 & 2 & 6,614 \\
\hline & 30 & 3,220 & 28 & 2,991 & 17 & 3,934 & 14 & 5,673 \\
\hline & 12 & 3,159 & 29 & 2,791 & 15 & 3,373 & 1 & 4,936 \\
\hline & 23 & 4,174 & 30 & 7,010 & 8 & 4,738 & 9 & 6,756 \\
\hline & 4 & 3,855 & 12 & 3,817 & 17 & 4,541 & 2 & 6,690 \\
\hline$\Xi$ & 12 & 3,400 & 26 & 3,478 & 20 & 4,481 & 12 & 6,661 \\
\hline & 17 & & 28 & 3,056 & 12 & 4,303 & 14 & 5,693 \\
\hline & 30 & 3.105 & 29 & 2,733 & 2 & 3,337 & 1 & 4,79 \\
\hline
\end{tabular}

Kaynak: WIOD, World Input-Output Database 'National Input-Output Tables, Released November 2013'ten faydalanılarak hesaplanmıştır.

2000 yılında Türkiye'de ileriye bağlantı etkisi en yüksek ilk üç sektör de 1995 yılına göre bir değişiklik olmamış, sadece sıralamaları değişmiştir. İleriye bağlantı etkisi açısından 12 no'lu Temel Metaller ve Metal üretimi birinci sırada yer almıştır. Almanya'da ileriye bağlantı etkisi en yüksek ilk üç sektör 1995 yılı ile aynı iken, Rusya'da 20 no'lu Motorlu Araçlar ve Motosikletler Dışında Toptan Ticaret ve Komisyon Ticaret, 12 no'lu Temel Metaller ve Metal üretimi ile 17 no'lu Elektrik, Gaz ve Su Temini sektörleri olmuştur. Çin'de de bir önceki dönemde olduğu gibi ileriye bağlantı etkisi açısından ilk iki sektör aynıdır. Ancak 3. Sektör 14 no’lu Elektrik ve Optik Ekipmanlar olarak farklılık göstermektedir.

Almanya, Rusya, Çin ve Türkiye'nin 2005 yılına ait ters Leontief matrisleri satır toplamlarına göre, Türkiye'de ileriye bağlantı etkisi en yüksek ilk üç sektör 12 no'lu Temel Metaller ve Metal üretimi, 23 no'lu Yurtiçi Taşımacılık ve 9 no'lu Kimyasallar ve Kimyasal Ürünlerdir. Almanya'da ileriye bağlantı etkisi en yüksek ilk üç sektör 30 no'lu Makine\&Ekipman ve Diğer İş Faaliyetleri kiralanması, 26 no'lu Diğer Destekleyici ve Yardımcı Ulaştırma ile Seyahat Acentaları Faaliyetleri ve 28 no'lu Finansal Aracılık'tır. Aynı yılda Rusya'da ilk üç sektör 17 no'lu Elektrik, Gaz ve Su Temini, 20 no'lu Motorlu Araçlar ve Motosikletler Dişında Toptan Ticaret ve Komisyon Ticaret ile 2 no'lu Madencilik ve Taşocakçıllğı sektörleridir. Çin'de ise ilk üç sektör 9 no'lu Kimyasallar ve Kimyasal Ürünler, 12 no'lu Temel Metaller ve Metal üretimi ile 2 no'lu Madencilik ve Taşocakçılığı'dır.

2008 y1lında Türkiye'de ileriye bağlantı etkisi en yüksek ilk sektör 23 no'lu Yurtiçi taşımacılık olmuştur. İkinci sıraya ise 2005 yılında dokuzuncu sırada yer alan 4 no'lu Tekstil ve tekstil ürünleri yükselmiştir. Almanya' da ileriye bağlantı etkisi en yüksek ilk üç sektör 30 no'lu Makine\&Ekipman ve Diğer İş Faaliyetleri kiralanması, 12 no'lu Temel Metaller ve Metal üretimi ve 26 no'lu Diğer Destekleyici ve Yardımcı Ulaştırma ile Seyahat Acentaları Faaliyetleri'dir. Rusya'da ise ilk üç sektör, 12 no'lu Temel Metaller ve Metal üretimi, 8 no'lu Rafine Petrol ve Nükleer Yakıt ile 20 no'lu Motorlu Araçlar ve Motosikletler Dışında Toptan Ticaret ve Komisyon Ticaret olmuştur. Çin'de ise ileriye bağlantı etkisi en yüksek ilk üç sektör 2005 y1lı ile benzer bir siralama göstermiştir. 
2011 yılında Türkiye, Almanya ve Çin'de ileriye bağlantı etkisi en yüksek üç sektör 2008 yılı ile aynı iken, Rusya'da ilk üç sektör; 8 no’lu Rafine Petrol ve Nükleer Yakıt, 17 no'lu Elektrik, Gaz ve Su Temini ile 20 no'lu Motorlu Araçlar ve Motosikletler Dışında Toptan Ticaret ve Komisyon Ticaret olmuştur.

Tablo 5: Yıllara göre Türkiye, Almanya, Rusya ve Çin'in Ters İthalat Matrisleri Sütun Toplamları (Geriye Bağlantı Etkileri)

\begin{tabular}{|c|c|c|c|c|c|c|c|c|}
\hline & \multicolumn{2}{|c|}{ TÜRKIYYE } & \multicolumn{2}{|c|}{ ALMANYA } & \multicolumn{2}{|c|}{ RUSYA } & \multicolumn{2}{|c|}{ ÇìN } \\
\hline & $\begin{array}{r}\text { Sek. } \\
\text { No }\end{array}$ & $\begin{array}{c}\text { Sütun } \\
\text { Top. }\end{array}$ & $\begin{array}{r}\text { Sek. } \\
\text { No }\end{array}$ & $\begin{array}{c}\text { Sütun } \\
\text { Top. }\end{array}$ & $\begin{array}{r}\text { Sek. } \\
\text { No }\end{array}$ & $\begin{array}{r}\text { Sütun } \\
\text { Top. }\end{array}$ & $\begin{array}{r}\text { Sek. } \\
\text { No }\end{array}$ & $\begin{array}{c}\text { Sütun } \\
\text { Top. }\end{array}$ \\
\hline \multirow{5}{*}{ 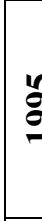 } & 8 & 0,260 & 8 & 0,319 & 4 & 0,243 & 14 & 0,222 \\
\hline & 10 & 0,220 & 4 & 0,246 & 5 & 0,182 & 8 & 0,206 \\
\hline & 9 & 0,189 & 5 & 0,235 & 10 & 0,168 & 5 & 0,189 \\
\hline & 15 & 0,185 & 15 & 0,222 & 15 & 0,164 & 10 & 0,180 \\
\hline & 5 & 0,179 & 12 & 0,216 & 13 & 0,143 & 4 & 0,178 \\
\hline \multirow{5}{*}{ હิ } & 8 & 0,426 & 8 & 0,480 & 4 & 0,344 & 8 & 0,302 \\
\hline & 14 & 0,297 & 15 & 0,293 & 10 & 0,228 & 14 & 0,263 \\
\hline & 15 & 0,269 & 5 & 0,267 & 5 & 0,225 & 10 & 0,190 \\
\hline & 10 & 0,260 & 4 & 0,263 & 15 & 0,203 & 4 & 0,182 \\
\hline & 9 & 0,233 & 12 & 0,259 & 9 & 0,188 & 9 & 0,181 \\
\hline \multirow{5}{*}{ 气气 } & 8 & 0,681 & 8 & 0,527 & 15 & 0,319 & 14 & 0,389 \\
\hline & 17 & 0,345 & 15 & 0,321 & 4 & 0,235 & 8 & 0,361 \\
\hline & 12 & 0,336 & 12 & 0,307 & 10 & 0,176 & 13 & 0,259 \\
\hline & 15 & 0,322 & 5 & 0,299 & 13 & 0,164 & 10 & 0,257 \\
\hline & 14 & 0,303 & 4 & 0,285 & 5 & 0,149 & 15 & 0,254 \\
\hline \multirow{5}{*}{ 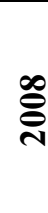 } & 15 & 0,341 & 8 & 0,637 & 15 & 0,380 & 8 & 0,424 \\
\hline & 12 & 0,324 & 12 & 0,375 & 4 & 0,179 & 14 & 0,326 \\
\hline & 16 & 0,298 & 15 & 0,357 & 13 & 0,165 & 12 & 0,258 \\
\hline & 14 & 0,236 & 25 & 0,330 & 10 & 0,154 & 9 & 0,245 \\
\hline & 4 & 0,228 & 4 & 0,303 & 25 & 0,141 & 10 & 0,236 \\
\hline \multirow{5}{*}{$\overline{\mathrm{N}}$} & 15 & 0,355 & 15 & 0,368 & 15 & 0,333 & 8 & 0,435 \\
\hline & 12 & 0,315 & 12 & 0,367 & 4 & 0,206 & 14 & 0,303 \\
\hline & 16 & 0,301 & 4 & 0,314 & 10 & 0,169 & 12 & 0,273 \\
\hline & 4 & 0,252 & 5 & 0,307 & 13 & 0,152 & 9 & 0,243 \\
\hline & 14 & 0,243 & 14 & 0,304 & 5 & 0,136 & 13 & 0,234 \\
\hline
\end{tabular}

Kaynak: WIOD, World Input-Output Database 'National Input-Output Tables, Released November 2013'ten faydalanılarak hesaplanmıștır.

Türkiye ile Almanya, Rusya ve Çin için hesaplanan ters ithalat matrislerinin dönemler itibariyle geriye ve ileriye bağlantı etkilerini gösteren sütun ve satır toplamları ilk 5 sektöre göre aşağıdaki tablolarda verilmiştir.

Tablo 5'e göre; 1995 yılında Türkiye'de ithalatta geriye bağlantı etkisi en yüksek ilk sektör 8 no'lu Rafine Petrol ve Nükleer Yakıt, 10 no'lu Kauçuk ve Plastik ve 9 no'lu Kimyasallar ve Kimyasal Ürünlerdir. Almanya'da geriye bağlantı etkisi en yüksek ilk üç sektör 8 no'lu Rafine Petrol ve Nükleer Yakıt, 4 no'lu Tekstil ve Tekstil Ürünleri ile 5 no'lu Deri, Deri ve Ayakkabı'dır. Aynı yılda Rusya'da geriye bağlantı etkisi en yüksek ilk üç sektör, 4 no'lu Tekstil ve Tekstil Ürünleri ile 5 no'lu Deri, Deri ve Ayakkabı ile 10 no'lu Kauçuk ve Plastik'tir. Çin'in geriye bağlantı etkisi en yüksek ilk üç sektörü; 14 no'lu Elektrik ve Optik Ekipmanlar ile 8 no'lu Rafine Petrol ve Nükleer Yakıtlar ile 5 no'lu Deri, Deri ve Ayakkabı'dır.

Tablo 5'e göre 2000 yılında Rusya dışında tüm ülkelerin ithalatta geriye bağlantı etkisi en yüksek sektörü 8 no'lu Rafine Petrol ve Nükleer Yakıt iken, Rusya'da 1. sırada 4 no'lu Tekstil ve Tekstil Ürünleri'dir. İthalatta geriye bağlantı etkisi açısından 2. ve 3. sektörler olarak Türkiye'de 14 no'lu Elektrik ve Optik Ekipmanlar ve 15 no'lu Ulaştırma Ekipmanları yer 
almaktadır. Bu sıralama; Almanya'da 15 no'lu Ulaştırma Ekipmanları ve 5 no'lu Deri, Deri ve Ayakkabı; Rusya'da 10 no'lu Kauçuk ve Plastik ve 5 no'lu Deri, Deri ve Ayakkabı; Çin de ise 14 no'lu Elektrik ve Optik Ekipmanlar ve 10 no'lu Kauçuk ve Plastik'tir.

2005 y1lında Türkiye ile Almanya'da ithalatta geriye bağlantı etkisi en yüksek sektörü yine 8 no'lu Rafine Petrol ve Nükleer Yakıttır. Rusya'da 15 no'lu Ulaştırma Ekipmanları ve Çin'de ise 14 no'lu Elektrik ve Optik Ekipmanlar ilk sırada yer almaktadır. Türkiye'de ithalatta geriye bağlantı etkisi açısından 2. sırada 17 no'lu Elektrik, Gaz ve Su Temini, 3. sırada ise 12 no'lu Temel Metaller ve Metal üretimi bulunmaktadır. İthalatta geriye bağlantı etkisi açısından 2. ve 3. sektörler olarak; Almanya'da 15 no'lu Ulaştırma Ekipmanları ve 12 no'lu Temel Metaller ve Metal üretimi; Rusya'da 4 no'lu Tekstil ve Tekstil Ürünleri ile 10 no'lu Kauçuk ve Plastik; Çin de ise 8 no'lu Rafine Petrol ve Nükleer Yakıt ve 13 no'lu Makine, (B. Y. S.) yer almaktadır.

2008 yılında Türkiye'de ithalatta geriye bağlantı etkisi en yüksek ilk üç sektör şöyle sıralanmaktadır: 15 no'lu Ulaştırma Ekipmanları, 12 no'lu Temel Metaller ve Metal üretimi ve 16 no'lu İmalat (B.Y.S) Geri Dönüşümdür. Bu sonuca bağlı olarak Türkiye'de önceki yıllara göre ithalatta geriye bağlantı etkisi yüksek sektörlerde bir değişiklik olduğu söyleyebiliriz.

2008'de Almanya'da geriye bağlantı etkisi en yüksek ilk üç sektör 8 no'lu Rafine Petrol ve Nükleer Yakıt, 12 no'lu Tekstil ve Tekstil Ürünleri ile 15 no'lu Deri, Deri ve Ayakkabıdır. Aynı yılda Rusya'da geriye bağlantı etkisi en yüksek ilk üç sektör, 15 no'lu, 4 no'lu Tekstil ve Tekstil Ürünleri ile 13 no'lu Makine, (B. Y. S.)'dir. Çin'in geriye bağlantı etkisi en yüksek ilk üç sektörü; 8 no'lu Rafine Petrol ve Nükleer Yakıtlar, 14 no'lu Elektrik ve Optik Ekipmanlar ile 12 no'lu Temel Metaller ve Metal üretimidir.

2011 yılına bakıldığında Türkiye'de ithalatta geriye bağlantı etkisi en yüksek üç sektör; 15 no'lu Ulaştırma Ekipmanları, 12 no'lu Temel Metaller ve Metal üretimi ve 16 no'lu İmalat (B.Y.S) Geri Dönüşüm 'dür. Almanya'da ise 15 no'lu Ulaştırma Ekipmanları, 12 no'lu Temel Metaller ve Metal üretimi ile 4 no'lu Tekstil ve Tekstil Ürünleridir. Rusya'da geriye bağlantı etkisi en yüksek ilk üç sektör; 15 no'lu Ulaştırma Ekipmanları, 4 no'lu Tekstil ve Tekstil Ürünleri ile 10 no'lu Kauçuk ve Plastiktir. Çin'de ise, geriye bağlantı etkisi en yüksek ilk üç sektör 8 no'lu Rafine Petrol ve Nükleer Yakıt, 14 no'lu Elektrik ve Optik Ekipmanlar ile 12 no'lu Temel Metaller ve Metal üretimidir.

Tablo 6 yıllara göre Türkiye, Almanya, Rusya ve Çin'in ters ithalat matrisleri satır toplamlarını, yani ileriye bağlantı etkilerini göstermektedir.

Tablo 6: Yıllara göre Türkiye, Almanya, Rusya ve Çin'in Ters İthalat Matrisleri Satır Toplamları (İleriye Bağlantı Etkileri)

\begin{tabular}{|c|c|c|c|c|c|c|c|c|}
\hline & \multicolumn{2}{|c|}{ TÜRKIYYE } & \multicolumn{2}{|c|}{ ALMANYA } & \multicolumn{2}{|c|}{ RUSYA } & \multicolumn{2}{|c|}{ ÇíN } \\
\hline & $\begin{array}{r}\text { Sek. } \\
\text { No }\end{array}$ & $\begin{array}{l}\text { Satır } \\
\text { Top. }\end{array}$ & $\begin{array}{r}\text { Sek. } \\
\text { No }\end{array}$ & $\begin{array}{l}\text { Satır } \\
\text { Top. }\end{array}$ & $\begin{array}{r}\text { Sek. } \\
\text { No }\end{array}$ & $\begin{array}{l}\text { Satır } \\
\text { Top. }\end{array}$ & $\begin{array}{r}\text { Sek. } \\
\text { No }\end{array}$ & $\begin{array}{l}\text { Satır } \\
\text { Top. }\end{array}$ \\
\hline & 9 & 0,683 & 9 & 0,569 & 12 & 0,401 & 14 & 0,703 \\
\hline & 2 & 0,605 & 12 & 0,453 & 9 & 0,397 & 9 & 0,584 \\
\hline & 12 & 0,357 & 14 & 0,362 & 13 & 0,351 & 12 & 0,433 \\
\hline & 14 & 0,300 & 2 & 0,325 & 4 & 0,300 & 2 & 0,406 \\
\hline & 15 & 0,230 & 7 & 0,228 & 2 & 0,151 & 4 & 0,324 \\
\hline \multirow{5}{*}{ ఫ్రి } & 2 & 0,985 & 9 & 0,690 & 9 & 0,715 & 14 & 0,838 \\
\hline & 9 & 0,941 & 2 & 0,628 & 4 & 0,436 & 2 & 0,705 \\
\hline & 12 & 0,561 & 12 & 0,503 & 13 & 0,418 & 9 & 0,696 \\
\hline & 14 & 0,433 & 14 & 0,484 & 12 & 0,410 & 12 & 0,390 \\
\hline & 15 & 0,337 & 15 & 0,295 & 15 & 0,278 & 4 & 0,262 \\
\hline \multirow{2}{*}{ సి } & 2 & 1,349 & 2 & 0,803 & 15 & 0,671 & 14 & 1,200 \\
\hline & 12 & 1,005 & 9 & 0,734 & 9 & 0,456 & 2 & 1,101 \\
\hline
\end{tabular}




\begin{tabular}{|c|c|c|c|c|c|c|c|c|}
\hline & 9 & 0,997 & 12 & 0,567 & 13 & 0,432 & 9 & 0,869 \\
\hline & 14 & 0,346 & 14 & 0,506 & 4 & 0,272 & 12 & 0,395 \\
\hline & 8 & 0,308 & 15 & 0,336 & 12 & 0,268 & 13 & 0,344 \\
\hline \multirow{5}{*}{ 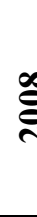 } & 12 & 0,977 & 2 & 1,052 & 15 & 0,946 & 2 & 1,512 \\
\hline & 15 & 0,387 & 9 & 0,810 & 13 & 0,414 & 14 & 0,932 \\
\hline & 4 & 0,380 & 12 & 0,728 & 9 & 0,345 & 9 & 0,661 \\
\hline & 26 & 0,242 & 14 & 0,475 & 4 & 0,244 & 12 & 0,300 \\
\hline & 9 & 0,224 & 8 & 0,369 & 12 & 0,218 & 1 & 0,259 \\
\hline & 12 & 0,918 & 9 & 0,925 & 15 & 0,710 & 2 & 1,633 \\
\hline & 4 & 0,448 & 12 & 0,775 & 9 & 0,399 & 14 & 0,753 \\
\hline & 15 & 0,437 & 14 & 0,583 & 13 & 0,387 & 9 & 0,607 \\
\hline & 26 & 0,262 & 15 & 0,382 & 4 & 0,308 & 12 & 0,288 \\
\hline & 8 & 0,260 & 8 & 0,370 & 12 & 0,216 & 13 & 0,284 \\
\hline
\end{tabular}

Kaynak: WIOD, World Input-Output Database 'National Input-Output Tables, Released November 2013'ten faydalanılarak hesaplanmıştır.

Tablo 6'ya göre 1995 yılında Türkiye'de ithalatta ileriye bağlantı etkisi en yüksek ilk sektör 9 no'lu Kimyasallar ve Kimyasal Ürünleriyken, 2. sirada 2 no'lu Madencilik ve Taşocakçılığ 1 , 3. sırada ise 12 no'lu Temel Metaller ve Metal üretimi bulunmaktadır. Aynı yıl Almanya'nın ilk üç sektörü 9 no'lu Kimyasallar ve Kimyasal Ürünler, 12 no'lu Temel Metaller ve Metal üretimi ile 14 no'lu Elektrik ve Optik Ekipmanlardır. Rusya'da ileriye bağlantı etkisi en yüksek ilk üç sektör 12 no'lu Temel Metaller üretimi, 9 no'lu Kimyasallar ve Kimyasal Ürünler ve 13 no'lu Makine, (B. Y. S.) üretimidir. Çin'de ise 1995 'te ileriye bağlantı etkisi en yüksek ilk üç sektör 14 no'lu Elektrik ve Optik Ekipmanlar, 9 no'lu Kimyasallar ve Kimyasal Ürünler ile 12 no'lu Temel Metaller ve Metal üretimidir.

2000 yılında Türkiye'de ithalatta ileriye bağlantı etkisi en yüksek ilk sektör 2 no'lu Madencilik ve Taşocakçılığı, 2. sırada 9 no'lu Kimyasallar ve Kimyasal Ürünleri iken, 3. sırada ise 12 no'lu Temel Metaller ve Metal üretimi bulunmaktadır. Aynı yıl Almanya'nın ilk üç sektörü 9 no'lu Kimyasallar ve Kimyasal Ürünler, 2 no'lu Madencilik ve Taşocakçılı̆̆ ile 12 no'lu Temel Metaller ve Metal üretimidir. Rusya'da ileriye bağlantı etkisi en yüksek ilk üç sektör 9 no'lu Kimyasallar ve Kimyasal Ürünler, 4 no'lu Tekstil ve Tekstil Ürünleri ile 13 no'lu Makine, (B. Y. S.) üretimidir. Çin'de ise 2000 'de ileriye bağlantı etkisi en yüksek ilk üç sektör 14 no'lu Elektrik ve Optik Ekipmanlar, 2 no'lu Madencilik ve Taşocakçılığı ile 9 no'lu Kimyasallar ve Kimyasal Ürünler üretimidir.

2005 yılına bakıldığında ise Türkiye'de ithalatta ileriye bağlantı etkisi en yüksek ilk sektör 2 no'lu Madencilik ve Taşocakçılığı iken, 2. sırada 12 no'lu Temel Metaller ve Metal üretimi, 3. sırada ise 9 no'lu Kimyasallar ve Kimyasal Ürünler bulunmaktadır. Aynı yıl Almanya'nın ilk üç sektörü 2 no'lu Madencilik ve Taşocakçılığı, 9 no'lu Kimyasallar ve Kimyasal Ürünler ile 12 no'lu Temel Metaller ve Metal üretimidir. Rusya'da ileriye bağlantı etkisi en yüksek ilk üç sektör 15 no'lu Ulaştırma Ekipmanları, 9 no'lu Kimyasallar ve Kimyasal Ürünler ve 13 no'lu Makine, (B. Y. S.) üretimidir. Çin'de ise 2005'te ileriye bağlantı etkisi en yüksek ilk üç sektör 14 no'lu Elektrik ve Optik Ekipmanlar, 2 no'lu Madencilik ve Taşocakçılığı ile 9 no'lu Kimyasallar ve Kimyasal Ürünlerdir.

2008 yılında Türkiye'de ithalatta ileriye bağlantı etkisi en yüksek ilk sektör 12 no'lu Temel Metaller ve Metal üretimi iken, 2. sırada 15 no'lu Ulaştırma Ekipmanları, 3. sırada ise 4 no'lu Tekstil ve Tekstil Ürünleri bulunmaktadır. Aynı yıl Almanya'nın ilk üç sektörü 2 no'lu Madencilik ve Taşocakçılığı, 9 no'lu Kimyasallar ve Kimyasal Ürünler ile 12 no'lu Temel Metaller ve Metal üretimidir. Rusya' da ileriye bağlantı etkisi en yüksek ilk üç sektör 15 no'lu Ulaştırma Ekipmanları, 13 no'lu Makine, (B. Y. S.) ile 9 no'lu Kimyasallar ve Kimyasal Ürünler üretimidir. Çin'de ise 2008 'de ileriye bağlantı etkisi en yüksek ilk üç sektör 2 no'lu 
Madencilik ve Taşocakçılığı, 14 no'lu Elektrik ve Optik Ekipmanlar ile 9 no'lu Kimyasallar ve Kimyasal Ürünler üretimidir.

Tablo 6'dan görüleceği gibi, 2011 y1lına ait bulgular incelendiğinde; Türkiye'de ithalatta ileriye bağlantı etkisi en yüksek ilk sektör 12 no'lu Temel Metaller ve Metal üretimi iken, 2. sırada 4 no'lu Tekstil ve Tekstil Ürünleri, 3. sırada ise 15 no'lu Ulaştırma Ekipmanları bulunmaktadır. Aynı yıl Almanya'nın ilk üç sektörü 9 no'lu Kimyasallar ve Kimyasal Ürünler, 12 no'lu Temel Metaller ve Metal üretimi ile 14 no'lu Elektrik ve Optik Ekipmanlardır. Rusya'da ileriye bağlantı etkisi en yüksek ilk üç sektör 15 no'lu Ulaştırma Ekipmanları, 9 no'lu Kimyasallar ve Kimyasal Ürünler ve 13 no'lu Makine, (B. Y. S.) üretimidir. Çin'de ise ileriye bağlantı etkisi en yüksek ilk üç sektör 2008 yılındakilerle aynıdır.

\section{Sonuç ve Değerlendirme}

Türkiye büyüyen ekonomisi ile Çin, Rusya ve Almanya gibi ülkelerle yoğun ticari ilişkileri olan bir ülkedir. Diğer yandan Türkiye'nin ithalatı açısından bakılırsa bu üç ülke en fazla ithalat yapılan ülkelerdir. Türkiye dinamik nüfusu, coğrafi konumu ve pazar payının büyüklügü ile bu ülkeler için iyi bir partner durumundadır. Çin, son zamanlarda ortalamada dünyanın en hızlı büyüyen ülkesi ve ekonomik yapı açısından bazı açılardan Türkiye'nin rakibi olan bir ülke, Rusya Federasyonu zengin doğal kaynakları ile Türkiye ekonomisi ile tamamlayıcılık ilişkileri yoğun olan bir ekonomi, Almanya ise yüksek ihracat rakamları, üretim yapısı ve tarihsel nedenlerle uzun zamandır Türkiye'nin en büyük ticari ortaklarından birisidir.

Diğer yandan Türkiye gelişmiş ülkeler sınıfına girmek istiyorsa belirli bir hızla büyümesi gereken bir ülkedir. Büyüme hızının ise ülkenin ekonomik yapısına sıkı sıkıya bağlı olduğu bilinen bir gerçektir. İktisat yazınında iyi bilinen Girdi-Çıktı analizi yöntemine dayalı olarak Türkiye'nin ekonomik olarak ilişkilerinin yoğun olduğu ve ithalatında ise en fazla paya sahip olan Çin, Almanya ve Rusya ile olan ekonomik ilişkileri göz önüne alınarak bir analiz yapılmıştır. Türkiye ihracatını her geçen gün artırmaktadır ancak ihracatın artması ithalat miktarını da artırmaktadır. Bir başka değişle ihracatı ithalata bağımlı ve ithalata bağımlı büyüyen bir yapıya sahiptir. Türkiye ithalat bağımlısı bir ülke olarak imalat sanayinin kilit endüstrileri arasındaki bağınlaşma azalmakta, bu ise endüstrilerin kendi alt sektörlerini destekleme ve çoğaltma etkisini azaltmaktadır. Türkiye de uygulanan ekonomi politikaları ülkeyi ithalat bağımlılı̆̆ı konusunda kısır döngüye sokmuş görünmektedir. İthalat bağımlılığı yatırımların azalmasına, işsizliğin çoğalmasına, ödemeler bilançosu açıklarının devam etmesine, döviz kıtlığına ve son zamanlarda görülen kur dalgalanmalarının aşırı oynaklığına sebep olabilmektedir. Buradan hareketle ithalatı mutlak olarak azaltmak ya da sifirlamak ne mümkün ne de gereklidir. Ancak katma değeri ülke içerisinde oluşan, teknolojik yatırımları hızlandıracak bir ekonomik yapıya sahip olmak gereklidir. Bunun için ise kilit endüstrilerin bağınlaşma oranlarını artıracak ve sektörel bağlantıları çoğaltacak ekonomik yapı, yüksek katma değer üreten üretim modeline geçilmelidir.

Çalışmada Türkiye ile beraber Çin, Rusya Federasyonu ve Almanya'nın 1995, 2000, 2005, 2008 ve 2011 yılı verileri kullanılarak Girdi-Çıktı analiz yöntemi ile ekonomik yapıları ve kilit endüstrileri tespit edilmiştir. Buna göre 2011 yılı verilerine göre Türkiye için Ters Leontief matrisleri sütun toplamlarına (geriye bağlantı etkisine) göre en yüksek sektörlere bakıldığında 4 no'lu Tekstil ve Tekstil Ürünleri, 16 no'lu İmalat (B.Y.S.) Geri Dönüşüm ve 12 no'lu Temel Metaller ve Metal üretimi olmaktadır. Aynı yıl Almanya için 15 no'lu Ulaştırma Ekipmanları, 8 no'lu Rafine Petrol ve Nükleer Yakıt ve 25 no'lu Hava Taşımacılığı olmaktadır. Rusya için 15 no'lu Ulaştırma Ekipmanları, 10 no'lu Kauçuk ve Plastik ve 25 no'lu Hava Taşımacılığı olmaktadır. Çin için 14 no'lu Elektrik ve Optik Ekipmanlar, 15 no'lu Ulaştırma Ekipmanları ve 10 no'lu Kauçuk ve Plastik olmaktadır. 
Yine 2011 yılı verilerine göre Ters Leontief matrisleri satır toplamlarına (ileriye bağlantı etkisine) göre Türkiye için 23 no'lu Yurtiçi Taşımacılık, 4 no'lu Tekstil ve Tekstil Ürünleri ve 12 no'lu Temel Metaller ve Metal üretimi olmaktadır. Almanya için 30 no'lu Makine ve Ekipman ve Diğer İş Faaliyetleri kiralanması, 12 no'lu Temel Metaller ve Metal üretimi ve 26 no'lu Diğer Destekleyici ve Yardımcı Ulaştırma Faaliyetleri; Seyahat Acentaları Faaliyetleri olmaktadır. Rusya için 8 no'lu Rafine Petrol ve Nükleer Yakıt, 17 no'lu Elektrik, Gaz ve Su Temini, 20 no'lu Motorlu Araçlar ve Motosikletler Dişında Toptan Ticaret ve Komisyon Ticaret olmakta. Çin için ise 9 no'lu Kimyasallar ve Kimyasal Ürünler 2 no'lu Madencilik ve Taşocakçılığı ve 12 no'lu Temel Metaller ve Metal üretimi olmaktadır.

Sonuçlardan da anlaşıldığı üzere Türkiye için geriye bağlantı etkisi ile ileriye bağlantı etkileri ilk sıralarda olmak üzere ortak sektörlerde (4 ve 12 nolu sektörler) toplanmaktadır. $\mathrm{Bu}$ ise ithalata bağımlı üretim modelini göstermektedir. Diğer ülkeler için ilk üç sektörde böyle bir eşleşme görülmemektedir.

\section{Kaynakça}

Andrew, R. M., \& Peters, G. P. (2013). a Multi-Region Input-Output Table Based on the Global Trade Analysis Project Database (Gtap-Mrio). Economic Systems Research, 25(1), 99-121. http://doi.org/10.1080/09535314.2012.761953

Barış, S., (2007), "Çin'in Makro Ekonomik Performansının Analizi” T.C. Kahramanmaraş Sütçü İmam Üniversitesi Sosyal Bilimler Enstitüsü, Yayınlanmamış Yüksek Lisans Tezi

Bayramoğlu, T., Durmaz, A. ve Ari, Y. O., (2015), Ekonomik Açıdan Terör ve Turizm İlişkisi, Türkiye Klinikleri J Foren Med-Special Topics 2015;1( 2):25-34.

Cesim Ç., (2016), Türkiye'nin ihracat Potansiyelinin Artırılması Kapsamında Çin'in İhracat Politikalarının Değerlendirilmesi, Uzmanlık Tezi, Kalkınma Bakanlı̆̆l, Ekonomik Modeller Ve Stratejik Araştırmalar Genel Müdürlüğü.

Ersungur, Ş. M., (2016), Bölgesel İktisat, Teori, Politika ve Uygulama, 4. Bask1, İmaj Yayınevi, Ankara.

Ersungur, Ş. M., ve Ekinci, D. E. (2015). Atatürk Üniversitesi, İktisadi ve İdari Bilimler Dergisi, 29(4), 721-749.

Gündoğdu, C., and Saracoğlu, D. Ş. (2016). Participation of Turkey in Global Value Chains : An Analysis Based on World Input Output Database (No. 16/10). Ankara.

Hasan, K. ve Batuhan U., (2011), Çin Halk Cumhuriyeti Büyük İnci Nehri Deltası, Ekonomi Bakanlığı, İhracat Genel Müdürlüğü, Ülke Masaları II

ITC, Trade Map, http://www.trademap.org/Bilateral_TS.aspx

İTKİB Genel Sekreterliği Tekstil Deri ve Halı Şubesi, (2016), Almanya Ülke Raporu, , Ocak 2016.

Kizilaslan, H., (2009). Input-output energy analysis of cherries production in Tokat Province of Turkey. Applied Energy, 86(7-8), 1354-1358. http://doi.org/10.1016/j.apenergy.2008.07.009

Koray A. K. ve Batuhan U., (2013), Çin Halk Cumhuriyeti Konsept Mağazacılık Pazar araştırması, Ekonomi Bakanlığı, İhracat Genel Müdürlüğü, Ülke Masaları II

Külekçi, M., and Aksoy, A. (2014). Input-Output Energy Analysis in Pistachio Production of Turkey. Environmental Progress \& Sustainable Energy, 32(1), 128-133. http://doi.org/10.1002/ep

McMillan, J., and Naughton, B. (1992). How to reform a planned economy: lessons from China. Oxford Review of Economic Policy, 8(1), 130-143.

Sinan Ç., (2015), Dünya Gazetesi, http://www.dunya.com/gundem/cindeki-son-ekonomikgelismeler-uzerine-bir-degerlendirme, E.T. 18.10.2016

T.C. Ekonomi Bakanlığı, (2016), http://www.ekonomi.gov.tr/portal/faces/home/disIliskiler 
TASAM, (2016), "Çin Ekonomisinin Yapısal Dönüşümü ve Gelişmekte Olan Ülkeler Açısından Sonuçları”, http://www.tasam.org/tr, E.T: 17.10.2016

Tepav Ticaret Çalışmaları Merkezi, (2016), Rusya Federasyonu'nun Dünya Ticaret Örgütü’ne Katılımına İlişkin Değerlendirme, https://www.deik.org.tr, E.T. 28.10.2016

Trading Economics, http://www.tradingeconomics.com., E.T. 06.11.2016

TÜIK, Turizm İstatistikleri, http://www.tuik.gov.tr/, 2016, E.T. 28.10.2016

UNCTAD, (2016), World Invest Report, Investor Nationality: Policy Challenges, p.196

Ozkan, B., Akcaoz, H., and Fert, C. (2004). Energy input-output analysis in Turkish agriculture.

Renewable Energy, 29(1), 39-51. http://doi.org/10.1016/S0960-1481(03)00135-6

Özdil, T., and Turdalieva, A. (2014). Girdi-Çıktı Analizi Yaklaşımıyla Türkiye ve Kazakistan Ekonomilerinin Karşılaştırılması. Ege Akademik Bakış, 13(3), 383-398.

Pahlavan, R., Omid, M., and Akram, A. (2012). Energy input-output analysis and application of artificial neural networks for predicting greenhouse basil production. Energy, 37(1), 171176. http://doi.org/10.1016/j.energy.2011.11.055

Pietroforte, R., and Gregori, T. (2003). An input-output analysis of the construction sector in highly developed economies. Construction Management and Economics, 21(3), 319-327. http://doi.org/10.1080/0144619032000056153

Rohman, I. K., (2013). The globalization and stagnation of the ICT sectors in European countries: An input-output analysis. Telecommunications Policy, 37(4-5), 387-399. http://doi.org/10.1016/j.telpol.2012.05.00

Trading Economics, http://www.tradingeconomics.com., E.T. 06.11.2016.

WIOD, (2013). World Input-Output Database 'National Input-Output Tables, Released November 2013.

UNCTAD, (2016), World Invest $\quad$ Report, $\quad$ s. 196. http://unctad.org/en/pages/PublicationWebflyer.aspx?publicationid=1555

Zhang, W., Peng, S., and Sun, C. (2015). CO2 emissions in the global supply chains of services: An analysis based on a multi-regional input-output model. Energy Policy, 86, 93-103. http://doi.org/10.1016/j.enpol.2015.06.029 